Pr onot er /r epr essor syst em of Lact obaci I I us pl ant ar um phage og1e: char act er i zat i on of the promoters pR49 pR pL and overproduct i on of the Cro- I i ke protei $n$ Cng i $n$ Escher i chi a col i

\begin{tabular}{|l|l|}
\hline 著者 & $\begin{array}{l}\text { KAK KAWA Naki ko, WATANABE Nobukat Su, } \\
\text { FUNAWATASH Tat suya, OW Nasaya, YASUKAWA } \\
\text { H r oo, TAKETO Aki r a, KODAl RA Ken- I chi }\end{array}$ \\
\hline $\begin{array}{l}\text { j our nal or } \\
\text { publ i cat i on ti t l e }\end{array}$ & Gene - Anst er dam \\
\hline vol une & 215 \\
\hline number & 2 \\
\hline page r ange & $371-379$ \\
\hline year & 1998 07 \\
\hline URL & ht t p: //hdl . handl e. net /10098/1626 \\
\hline
\end{tabular}




\title{
Promoter/repressor system of Lactobacillus plantarum phage øg1e: characterization of the promoters $p R 49-p R-p L$ and overproduction of the Cro-like protein Cng in Escherichia coli
}

\author{
Makiko Kakikawa ${ }^{\text {a }}$, Nobukatsu Watanabe ${ }^{\text {a }}$, Tatsuya Funawatashi ${ }^{\text {a }}$, Masaya Oki ${ }^{\text {a,1, }}$ \\ Hiroo Yasukawa ${ }^{a}$, Akira Taketo ${ }^{\mathrm{b}}$, Ken-Ichi Kodaira ${ }^{\mathrm{a}}$ \\ ${ }^{a}$ Molecular Biology Group, Faculty of Engineering, Toyama University, 3190, Gofuku, Toyama 930, Japan \\ ${ }^{b}$ Department of Biochemistry I, Fukui Medical School, Matsuoka, Fukui 910-11, Japan
}

\begin{abstract}
The Lactobacillus plantarum phage øgle ( $42259 \mathrm{bp}$ ) has two repressor-like genes cng and cpg oriented oppositely, accompanied by three potential promoters $p R, p L$ and $p R 49$, and seven operator-like sequences (GATAC-boxes) (Kodaira et al., 1997). In this study, the $\varnothing \mathrm{gle}$ putative promoters were introduced into the Escherichia coli promoter-detecting plasmid pKK232-8. In E. coli CK111, $p R$ (pKPR1), $p L$ (pKPL1) and $p R 49$ (pKPR 49) exhibited distinct CAT activities. When pKPR1 or pKPL1 was coexistent with a compatible plasmid pACYC184 carrying $p R$-cng (pA4PRCN1), the CAT activity was decreased significantly. On the other hand, cng directed a protein $(\mathrm{Cng})$ of $10.1 \mathrm{kDa}$ in $E$. coli under the control of T7 promoter. Gel mobility-shift assays demonstrated that $\mathrm{Cng}$ binds specifically to a DNA region containing the GATAC-boxes. In addition, primer extension analyses demonstrated that the two sequences $p R$ and $p L$ act as a promoter in $L$. plantarum as well as in $E$. coli. These results suggested that the potential promoters $p R$ and $p L$ probably function for the lytic and lysogenic pathways, respectively, and Cng may act as a repressor presumably through the GATAC-boxes as operators.
\end{abstract}

Keywords: DNA-binding protein; Gel-shift assay; Operator; Primer extension

\section{Introduction}

Prevalence of lysogeny in various Gram-positive and -negative bacteria has been reported (Davidson et al.,
1990; Campbell, 1994). For their propagation in two different ways (lysis or lysogeny), it has been thought that the phages have a set of regulatory proteins, as well as their recognizable DNA domains.

In Escherichia coli phages such as lambda, P2 and 186, the lysis-lysogeny decision depends upon phageencoded proteins, known as repressors, which regulate gene expression by binding to specific DNA sequences called operators (Campbell, 1994; Neufing et al,, 1996). Contrary to the coliphages, molecular details on the lysis-lysogeny switch of the phages from lactic acid bacteria are scanty, although several putative repressor/operator systems have been reported, e.g., the Lactococcus phages rlt (Nauta et al., 1996), BK5-T (Boyce et al., 1995) and Tuc2009 (van de Guchte et al., 1994).

Recently, we isolated a new Lactobacillus plantarum temperate phage øgle (Kakikawa et al., 1996), and determined the total genome sequence of $42259 \mathrm{bp}$ DNA (Kodaira et al., 1997). The sequencing result revealed that a region of approx. $850 \mathrm{bp}$ of the $\varnothing \mathrm{gle}$ 
Table 1

Bacteria, phages and plasmids used in this study

\begin{tabular}{|c|c|c|}
\hline Strain & Genotype or construct & Source or reference \\
\hline \multicolumn{3}{|l|}{ Bacteria } \\
\hline \multicolumn{3}{|l|}{ Escherichia coli } \\
\hline CK 111 & recA & Lab. stock \\
\hline XLI-Blue & 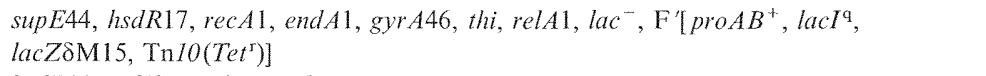 & Lab. stock \\
\hline BL21 (DE3) & hsdE44, gal $\lambda$ cI ts857, ind $1, \operatorname{Sam} 7$, nin 5, lacUV5-T7 gene 1$)$ & Studier et al. (1990) \\
\hline BL21(DE3)plysS & BL2I (DE3) containing plysS & Studier et al. (1990) \\
\hline \multicolumn{3}{|c|}{ Lactobacillus plantarum } \\
\hline Gle & $\mathrm{Tet}^{\mathrm{r}}, \mathrm{Km}^{\mathrm{r}}, \mathrm{lac}^{+}, \mathrm{suc}^{+}, \emptyset \mathrm{gle}$, pGle & Lab. stock \\
\hline \multicolumn{3}{|c|}{ 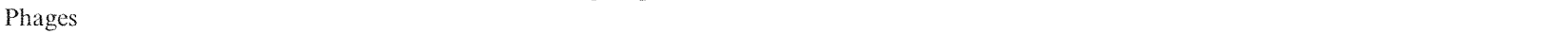 } \\
\hline$ø$ gle & 42259 bp template phage of L. plantarim G1e & Lab. stock \\
\hline \multicolumn{3}{|l|}{ Plasmids } \\
\hline pUC118 & 3162 bp E. coli vector, $A m p^{\mathrm{r}}$, plac, lac $\mathrm{Z}^{\prime}$ & Lab. stock \\
\hline $\mathrm{pKK} 232-8$ & 5096 bp E. coli promoter-detecting vector, Amp ${ }^{\mathrm{r}}$, containing promoterless cat & Brosius (1984) \\
\hline pACYC184 & $3.97 \mathrm{kbp} E$. coli vector, $T c^{\mathrm{r}}, \mathrm{Cm}^{\mathrm{r}}$ & Chang and Cohen (1978) \\
\hline $\mathrm{pET}-3 \mathrm{c}$ & Cloning vector containing $\mathrm{T} 7$ promoter & Studier et al. (1990) \\
\hline pl18PR1 & pUC118::454 bp AluI Rsal fragment from øgle ( $p R$ under plac) & This study \\
\hline pl18PLl & pUC1 18::454 bp AluI $\sim R s a l$ fragment from $ø g l e ~(p L$ under plac) & This study \\
\hline pKPR1 & pKK232-8::230 bp fragment from p118PR1 (cat under $p R$ ) & This study \\
\hline pKPLl & pKK232-8::227 bp fragment from p118PL1 (cat under $p L$ ) & This study \\
\hline pKPR49 & pKK232-8::141 bp fragment from p118PR1 (cat under $p R 49$ ) & This study \\
\hline pKPRCN1 & pKK232-8::471 bp fragment from p118PR1 (cat under $p R-p R 49$ ) & This study \\
\hline pA4PRCN1 & pACYC184::454 bp fragment from p118PR 1 & This study \\
\hline pE3CNGI & pET-3c::267 bp fragment from p118R1 containing cng under control of T7 promoter & This study \\
\hline
\end{tabular}

Table 2

Synthetic oligonucleotides used in this study

\begin{tabular}{|c|c|c|}
\hline Primers & Nucleotide sequence & Source \\
\hline CNGI & 5'-aacatATGAAGCGTGAGCGACTTATT-3' & in cng $(578-559)$ \\
\hline CNGII & $5^{\prime}$-aagggatcettATTTTGCTGCCTCCTTTGT-3' & in cng $(315-333)$ \\
\hline CNGVI & 5'-GCAATAAGTC $(\mathrm{a} / \mathrm{c}) \mathrm{CTCACGCTTC}-3^{\prime}$ & in $\mathrm{cng}(557-577)$ \\
\hline PL-PE1 & 5'-CTCATCTTGTGTCTTGCCTTGC-3' & in cng $(814-793)$ \\
\hline PR49-PE1 & 5'ACTACTAGGTTAGTAACTGATTG-3' & in $\operatorname{Lorf} 49(252-274)$ \\
\hline CAT-N & 5'-CATTTTAGCTTCCTTAGCTCCT-3' & in PKK232-8 $(271-250)$ \\
\hline M13RV & 5'-CAGGAAACAGCTATGAC-3' & in lac $Z^{\prime}$ \\
\hline M13-20 & 5'GTAAAACGACGGCCAGT-3' & in $l a c Z^{\prime}$ \\
\hline $\mathrm{M} 13-47$ & 5'-CGCCAGGGTTTTCCCAGTCACGAC-3' & in $l a c Z^{\prime}$ \\
\hline
\end{tabular}

Oligonucleotides used in this study (for PCR, DNA sequencing and primer extension) were obtained from KURABO (in cng, Lorf49 and pK232-8) and Takara (in lacZ'). Sequence positions given in øgle (cng and Lorf 49) and pKK232-8 were from Kodaira et al. (1997) and Brosius (1984), respectively. Artificial nucleotides shown in lower-case letters in CNGI, CNGII, or CNGVI are described in Section 3.1.

Table 3

CAT activity of $E$. coli CK111 carrying øgle-promoter-containing plasmids

\begin{tabular}{llll} 
& & \multicolumn{2}{c}{ CAT activity with $^{\mathrm{c}}$} \\
\cline { 3 - 4 } Plasmids $^{\mathrm{a}}$ & Promoter & No plasmid & pA4PRCN1 \\
\hline pKK232-8 & None & $<0.5$ & $<0.5$ \\
pKPR1 & $p R$ & 626.8 & 106.7 \\
pKRR49 & $p R 49$ & 12.8 & 10.1 \\
pKPL1 & $p L$ & 37.8 & 0.8 \\
\hline
\end{tabular}

CAT activity was assayed as described in Section 2.3 .

aplasmids containing $ø g$ le promoters $(p R, p R 49$ and $p L)$ upstream of cat are indicated in Fig. 2 (Table 1).

${ }^{\text {b}}$ Values, average of 3-5 experiments.

'Plasmid pA4PRCN1, coresident with promoter-containing plasmid. genome contains two repressor-like genes, $c n g$ and $c p g$, oppositely oriented at a distance of 166 bp away, accompanied by seven 15 bp inverted repeats (named GATACbox) and three potential promoter sequences for mRNA transcription. The predicted $c n g$ and $c p g$ proteins (Cng and Cpg, respectively) contain a potential helix-turnhelix DNA binding motif in the N-termini, like other repressor proteins from coliphages. øgle Cng (88 amino acids) somewhat resembles lambda Cro (Albright et al., 1996), whereas Cpg (132 amino acids) bears resemblance to lambda CI (Pabo and Sauer, 1984). In addition, the øgle genes for lytic pathway (e.g. virion proteins and cell lysis) are located downstream of cng, and the øgle integrase gene is encoded downstream of $c p g$ (Kakikawa et al., 1996, 1997; Oki et al., 1996, 1997; Kodaira et al., 
(A)

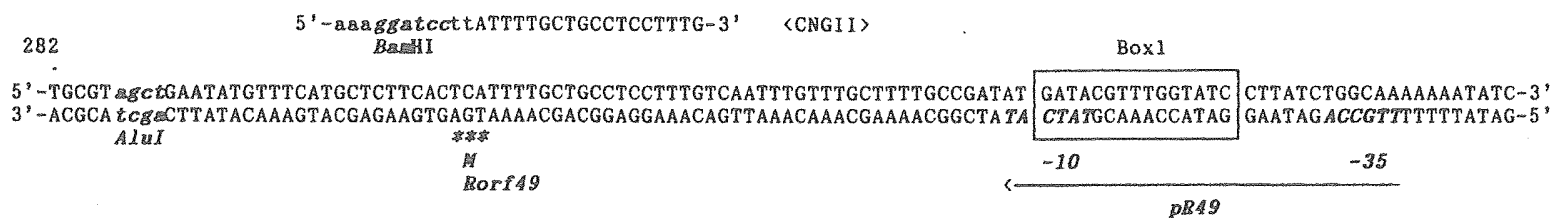

(B)

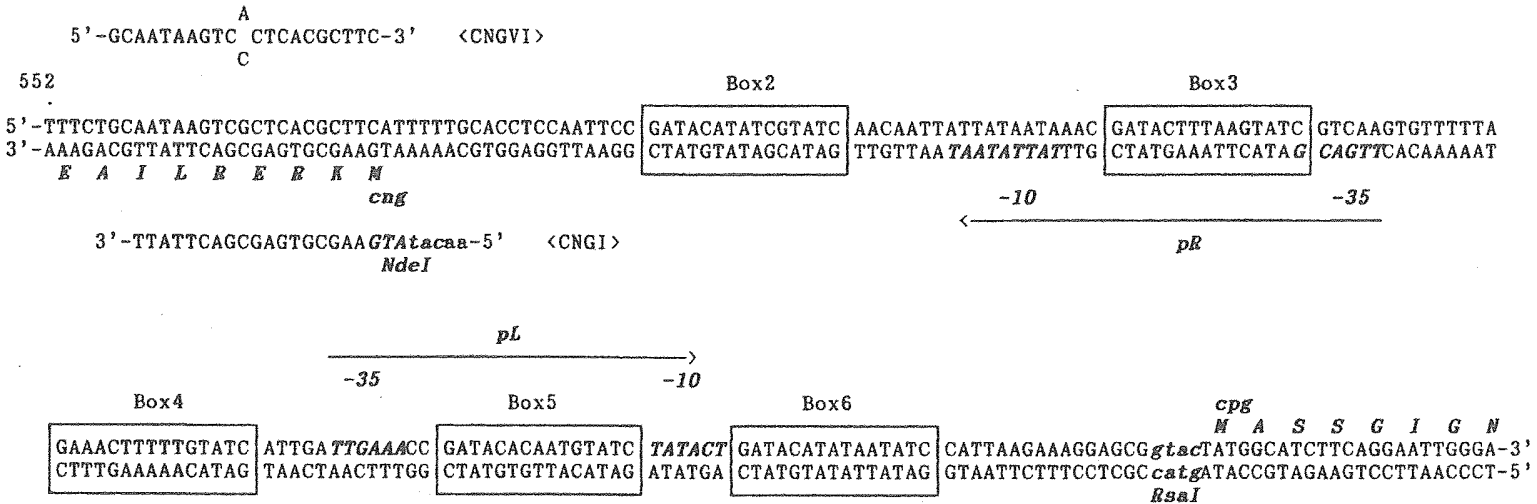

(C)

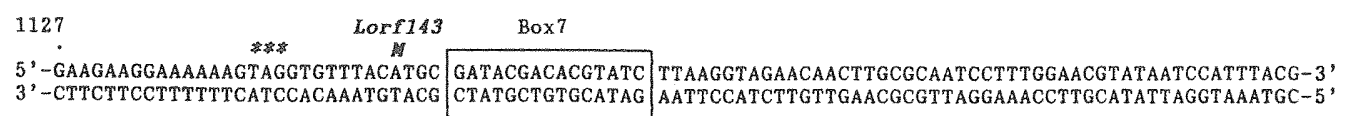

Fig. 1. DNA sequences of the øgle promoter/operators. The DNA sequences, nucleotide numbers, and putative genes and ORFs were from Kodaira et al. (1997) (EMBL accession number, X98106). The predicted promoters, $p L, p R$ and $p R 49$ are indicated by long arrows. The -35 and -10 sequences are shown by bold italic letters. The seven GATAC-boxes are boxed. (A) pR49 and box 1 . ***, stop codon for cng; $M$, start of Rorf 49 . The AluI site (lower-case bold letters) and the primer CNGII (Table 2) are also shown. (B) $p R-p L$ and boxes 2-6. The N-terminal amino acids of $c n g$ and cpg are shown. The RsaI site (lower-case bold letters) and the primers CNGI and CNGVI (Table 2) are shown. (C) Box 7. ***, stop codon for cpg; $M$, start of Lorf 143 .

1997; Yasukawa et al., 1997). These previous results suggest that the $c n g-c p g$ region functions as a regulatory domain for the lysis-lysogeny decision.

In the present study, function of the predicted $ø g l \mathrm{e}$ promoters was investigated in $E$. coli using cat as a reporter gene, and primer extension analyses were performed in L. plantarum as well as in E. coli. Moreover, Cng, a DNA-binding protein overproduced in E. coli, was characterized in vitro.

\section{Materials and methods}

\subsection{Bacteria, phage and plasmids}

The L. plantarum Gle and its temperate phage øgle were from our laboratory stock, and were propagated in M17 broth as described previously (Kakikawa et al., 1996). The E. coli vector plasmids (pUC118, pKK232-8,
pACYC184, pET-3c) and their host XL1-Blue were propagated in LB broth (Oki et al., 1996). The recombinant plasmids constructed in this study (see Sections 3.1 and 3.3) are summarized in Table 1 (see also Fig. 2).

\subsection{Analysis of DNA, RNA and protein}

Cloning and sequencing analyses of øgle DNA were carried out essentially as described by Kakikawa et al. (1996, 1997). Gel-shift assays were performed as described by Yasukawa et al. (1997): cell extracts of $E$. coli BL21(DE3)plysS carrying a plasmid were prepared by the lysozyme-freeze-thawing method, and the cell extract $(1 \mu \mathrm{g} / \mu \mathrm{l}$ of protein) was incubated with DNA fragment at $0^{\circ} \mathrm{C}$ for $20 \mathrm{~min}$ in $10 \mu \mathrm{l}$ of reaction buffer $[10 \mathrm{mM}$ Tris (pH 7.5), $1 \mathrm{mM}$ EDTA, $100 \mathrm{mM} \mathrm{KCl}$, $0.1 \mathrm{mM}$ DTT, $5 \%$ glycerol, $50 \mathrm{mg} / \mathrm{ml}$ bovine serum albumin, $1 \mu \mathrm{g} / \mathrm{ml}$ sheared salmon sperm DNA], and electrophoresed on a non-denaturing $6 \%$ polyacrylamide 

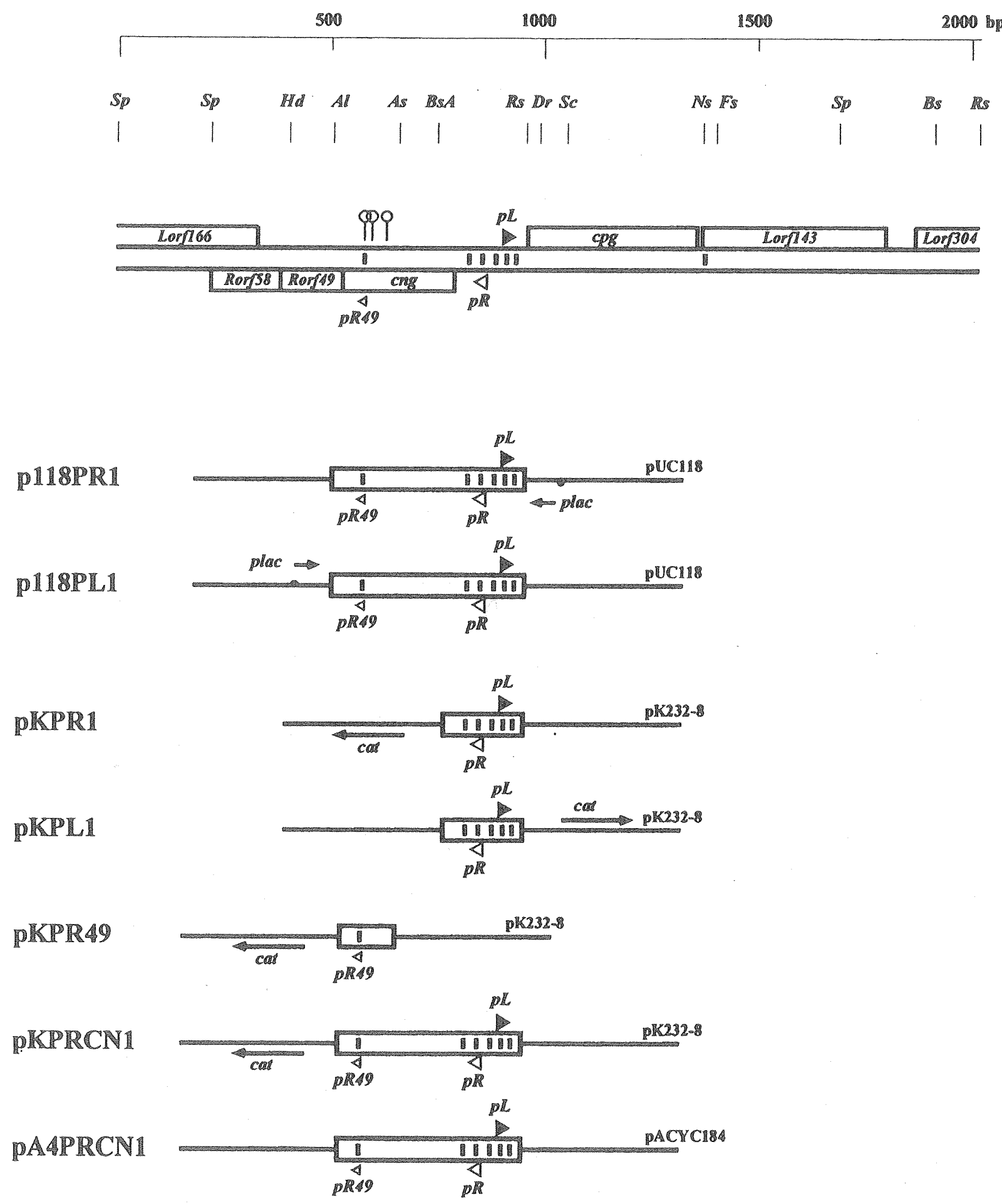

Fig. 2. Construction of the øgle promoter-containing plasmids. A 2030 bp physical map of the øgle genome is represented. $ø \mathrm{gle}$ DNA is shown by two thick lines. The putative genes and ORFs (see Fig. 1) are indicated by open boxes with their directions. The seven GATAC-boxes (see Fig. 1) are indicated by small closed boxes. The three promoters are indicated by $p L$ (closed arrowhead), $p R$ (open arrowhead) and $p R 49$ (small open arrowhead) above or below the ogle DNA, depending on their direction. The possible secondary structures (Kodaira et al, 1997) are shown by open circles with a bar. Restriction enzyme sites are shown in the top: Al, AluI; Bs, BsmI; BsA, BsmAI; Dr, DraI; Fs, FspI; $H d$, $H i n d I I$; $N s$, NspI; Rsa, RsaI; Sc,SacI; Sp, SphI. Under the physical map, the recombinant plasmids constructed (Section 3.1 ) are shown. $ø$ gle DNA regions are indicated by boxes, and vector plasmids are shown by thick lines. The directions of plac and cat are shown by arrows. 

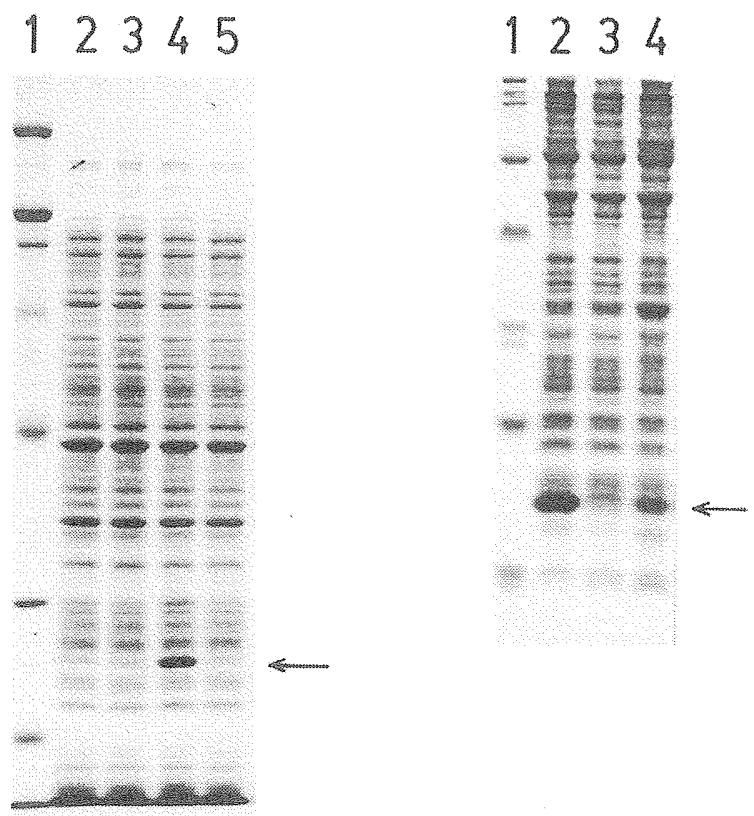

Fig. 3. Protein profiles. Cell extracts of $E$. coli XL1-Blue (A) or BL21(DE3) plysS (B) carrying a plasmid were subjected to SDS-PAGE (Section 2.2). Proteins were stained with Coomassie brilliant blue R-250. (A) The samples were electrophoresed on a $12.5 \%$ SDS gel. Lane 1, markers; lane 2, pKK232-8; lane 3, pKPL1; lane 4 , pKPR1; lane 5, pKPR 49. Arrow: an induced band (CAT). (B) The samples were electrophoresed on a $16.5 \%$ Tricine-SDS gel. Lane 1 , markers; lane 2, pE3CNG1 (after $2 \mathrm{~h}$ induction with IPTG); lane 3 , pET-3c $(2 \mathrm{~h})$; lane 4, pE3CNGl ( $1 \mathrm{~h})$. Arrow: an induced band (Cng).

gel containing $10 \%$ glycerol at $4^{\circ} \mathrm{C}$. For analysis of mRNA transcript, RNA was prepared as described by Oki et al. (1997): primer-extension analysis was followed by the method of Sambrook et al. (1989). For analysis of protein, SDS-PAGE was carried out as described by Kakikawa et al. (1996): proteins were visualized by staining with Coomassie Brilliant Blue (CBB) R-250. Tricine-SDS-PAGE was performed by the method of Ploug et al. (1989). The N-terminal amino acid sequence of the protein was determined as described by Kakikawa et al. (1996), using 490 Procise protein sequencing system (Applied Biosystems).

\subsection{CAT assay}

CAT activity was assayed by the method of Shaw (1975). E. coli carrying a plasmid(s) was grown in LB broth at $37^{\circ} \mathrm{C}$. When $A_{660}$ had reached 0.5 , the cells were harvested by centrifugation, and suspended in $50 \mathrm{mM}$ Tris $-\mathrm{HCl}$ buffer (pH 7.8) containing $30 \mu \mathrm{M}$ DTT. The cells were frozen by dry ice-ethanol bath, and thawed at $0^{\circ} \mathrm{C}$ for $6 \mathrm{~min}$. 1/50 volume of lysozyme $(15 \mathrm{mg} / \mathrm{ml}) /$ EDTA $(50 \mathrm{mM})$ was added, and incubated at $0^{\circ} \mathrm{C}$ for $30 \mathrm{~min}$. After freeze-thawing once more, cell debris was removed by centrifugation. The extracts were subjected to CAT assays.

\subsection{Enzymes and biochemicals}

Restriction enzymes, phage T4 DNA ligase, and reverse transcriptase (RAV-2) were purchased from Takara Shuzo (Kyoto). Buffers for each enzyme were as recommended by the manufacturer. Synthetic oligonucleotide primers for PCR and DNA sequencing are summarized in Table 2. $\left[\alpha-{ }^{32} \mathrm{P}\right] \mathrm{dCTP}$ was from NEN.

\section{Results}

\subsection{Construction of ogle promoter-containing plasmids}

Figs. 1 and 2 show the $ø$ gle $c n g-c p g$ region $(850 \mathrm{bp})$ containing the seven GATAC-boxes. Box 1 is located within cng (Fig. 1A), the five boxes 2-6 are between cng and cpg (Fig. 1B), and box 7 is downstream of $c p g$ (Fig. 1C). The three boxes 1, 3 and 5 overlap potential promoter sequences ( $p R 49, p R$ and $p L$, respectively), which share high similarity $(71.6,63.9$ and $62.7 \%$, respectively) with the $E$. coli promoter consensus ( -35 and -10 sequences: Harley and Reynolds, 1987).

As summarized in Table 1 (see Fig. 2), the ogle promoter-sequences were cloned into $E$. coli plasmids. A $456 \mathrm{bp}$ Alul/Rsal fragment containing $c n g / p R 49-p R-p L$ was introduced into a SmaI site of an $E$. coli vector $\mathrm{pUC118}$, yielding $\mathrm{p} 118 \mathrm{PR} 1(p R$ under plac) and p118PLl ( $p L$ under plac). Using p118PR1, a 231 bp DNA region of $p R-p L$ (containing truncated $c n g$ and $c p g$ ) was amplified by PCR using two synthetic oligonucleotide primers, CNGVI and M13-RV (Table 2). CNGV1 was arranged to convert fifth codon of cng from CGA(Arg) to TGA(stop codon) or GGA (Gly: changing to an uncharged residue) (Fig. 1B). The PCR product was cloned into a SmaI site upstream of cat in E. coli promoter-detecting plasmid pKK232-8, resulting in pKPRI $(p L p R-c a t)$ and $p K P L 1$ $(p R-p L-c a t)$. The cloned regions were confirmed by DNA sequencing. Expectedly, the fifth codon of cng in pKPR1 was changed from CGA(Arg) to TGA(stop codon), whereas that in pKPLl was changed to GGA(Gly), consequently yielding a truncated cng; fortuitously, both plasmids lacked one nucleotide at the 3 '-end of M13-RV, and pKPL1 (but not pKPR1) was deleted in three nucleotides $\left(5^{\prime}\right.$-GCA-3') from nucleotide position 557-559 in øg1e DNA (Fig. 1B). To place $p R 49$ upstream cat, a 141 bp fragment of p118PR1, containing pR49, was cut with AseI (Fig. 2) and introduced into a Smal site of pKK232-8, to yield pKPR49. In addition, a $484 \mathrm{bp}$ fragment containing $p L-p R-c n g / p R 49$ was amplified with two primers M13-RV and CNGII 

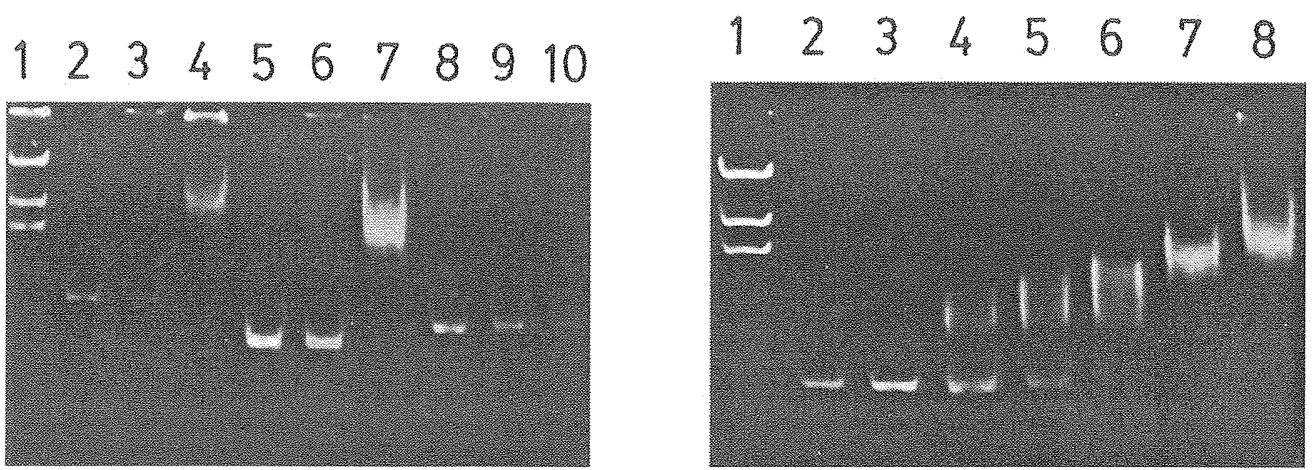

Fig. 4. Gel shift assays. Cell extracts of $E$. coli BL21(DE3)plys $S$ carrying a plasmid was incubated with DNA fragment at $0^{\circ} \mathrm{C}$ for $20 \mathrm{~min}$, and electrophoresed on a non-denaturing 6\% polyacrylamide gel (Section 2.2). The DNA bands were visualized by ethidium bromide staining. (A) Three DNA fragments used (each $1 \mu \mathrm{g}$ ) were as follows: a $300 \mathrm{bp}$ Asel/Rsal fragment (Fig. 2), lanes 2-4; a PCR-produced 231 bp fragment using CNGVI and M13-RV (Table 2), lanes 5-7; a $269 \mathrm{bp} \mathrm{Rsal} \mathrm{fragment} \mathrm{from} \mathrm{pUC118,} \mathrm{lanes} \mathrm{8-10.} \mathrm{Cell} \mathrm{extracts} \mathrm{(} 3 \mu \mathrm{lof} 1 \mu \mathrm{g} / \mu \mathrm{l}$ of protein) used were as follows: E. coli BL21(DE3)plysS (lanes 2, 5 and 8); E. coli BL21(DE3)plysS/pET-3c (lanes 3,6 and 9); E. coli BL21(DE3)plysS/pE3CNG1 (lanes 4, 7 and 10). Lane 1, Rsal fragments of pUCl18 as markers. (B) A PCR-derived 231 bp fragment as in (A) was incubated with various amounts of cell extract from E. coli BL21(DE3)plysS/pE3CNG1. Lane 1, Rsal fragments of pUC118 as markers. The ratios of DNA $(\mu \mathrm{g})$ and cell extract ( $\mu \mathrm{l})$ were as follows: lane $2,1 \mu \mathrm{g} /$ containing no cell extract; lane $3,1 \mu \mathrm{g} / 0.5 \mu \mathrm{l}$; lane $4,2 \mu \mathrm{g} / 1 \mu \mathrm{l}$; lane $5,3 \mu \mathrm{g} / 2 \mu \mathrm{l} ;$ lane $6,3 \mu \mathrm{g} / 3 \mu \mathrm{l}$; lane $7,3 \mu \mathrm{g} / 4 \mu \mathrm{l} ;$ lane $8,3 \mu \mathrm{g} / 5 \mu \mathrm{l})$.

(Table 2 and Fig. 1A) using p118PR1 DNA, and cloned into a Smal site of pKK232-8, yielding pKPRCN1. As shown in Fig. 1A, the stop codon of cng ( $5^{\prime}$-ATGA-3') overlaps a start codon of the putative ORF Rorf 49 $\left(5^{\prime}\right.$-ATGA-3'). Therefore, the primer CNGII was arranged to change the stop-codon of cng from TGA to TAA, so that this recombinant plasmid is no longer truncated in Rorf 49. By DNA sequencing, pKPRCN1 was found to be lacking in 2 bp $\left(5^{\prime}\right.$-CA-3') within M13-RV region.

\subsection{Promoter activities of $\mathrm{pR}, \mathrm{pR} 49$ and $\mathrm{pL}$}

E. coli cells (XL1-Blue or CK111) carrying pKPR1 grew in the presence of up to $400 \mu \mathrm{g} / \mathrm{ml}$ of $\mathrm{Cm}$. On the other hand, the upper limit of $\mathrm{Cm}$ resistance in $E$. coli cells containing pKPLl or pKPR49 was about $200 \mu \mathrm{g} / \mathrm{ml}$. Subsequently, CAT activities associated with pKPR1, pKPL1, or pKPR49 were assayed (Section 2.3). In $E$. coli CK111, the mean value of pKPR1 was 626.8 (units/mg), and those of pKPL1 and pKPR49 were 37.8 and 12.8 , respectively, whereas that of pKK232-8 was
0.5 (Table 3 ). These results indicate that $p R, p R 49$ and $p L$ function as a promoter, and $p R$ has the strongest activity, at least in $E$. coli. In addition, total proteins were extracted from XL1-Blue carrying $\mathrm{pKPR} 1$, pKPL1, or pKPR49, and subjected to SDS-PAGE (Fig. 3A). In pKPR1, steadily increasing synthesis of a protein was detected; this overproduced protein (apparent molecular mass $26.5 \mathrm{kDa}$ ) was probably chloramphenicol acetyltransferase $(25.7 \mathrm{kDa}$ estimated from DNA sequence: Brosius, 1984).

On the other hand, pKPRCN1 containing $p L-p R-c n g / p R 49$ (Section 3.1) exhibited lower CAT activity (one-sixth of pKPR1), suggesting that cng probably functions as a repressor. To investigate this repressive activity of Cng, a 454 bp Rsal/Hincll fragment containing $p L-p R-c n g / p R 49$ was cut from $\mathrm{pKPRCN} 1$, and then introduced into pACYC184 at a blunted EcoRI site, yielding pA4PRCN1 ( $p R$ : opposite to the CM gene of pACYC184). When pKPR1, pKPL1, or pKPR49 was coexistent with pA4PRCN1 in E. coli CK111, the CAT activities of pKPR1 and pKPL1 (but not pKPR49) were reduced significantly (Table 3 ). These results sug-

Fig. 5. Primer extension analyses. Total RNA was isolated from cells of E. coli carrying a plasmid or $L$. plantarum, and cDNA synthesized by reverse transcriptase was analyzed, along with DNA sequencing ladders, on $6 \%$ polyacrylamide gels (Section 2.2 ). The relevant nucleotide sequences are indicated in the left-hand margins. The major transctiption start points are represented by closed circles. The putative mRNA promoters are shown by -35 and - 10. (A) Mapping of the transcription start sites from $p R$ (a: lane 1), $p L$ (b: lane 1) and $p R 49$ (c: lane 1 ) in $E$. coli. RNA was from $E$. coli XL1-Blue/ pKPRI (for $p R$ ), XL1-Blue/pKPL1 (for $p L$ ), or XL1-Blue/pKPRCN1 (for $p R 49$ ), and cDNA was synthesized with a primer (Table 2), CNGVI (for $p R$ ), M13RV ( $p L$ ), or CAT-N (for $p R 49$ ). (B) Mapping of the transcription start sites from $p R$ (a), $p L$ (b) and $p R 49$ (c) in L. plantarum. RNA was from L. plantarum Gle untreated with MMC (lane 1) or treated with $M M C$ (final concentration: $5 \mu \mathrm{g} / \mathrm{ml}$ ) for $2 \mathrm{~h}$ (lane 2). cDNA was synthesized with a primer (Table 2), CNGVI (for $p R$ ), PL-PEl (for $p L$ ), or PR49-PE1 (for $p$ R49). 
(A)

(a)

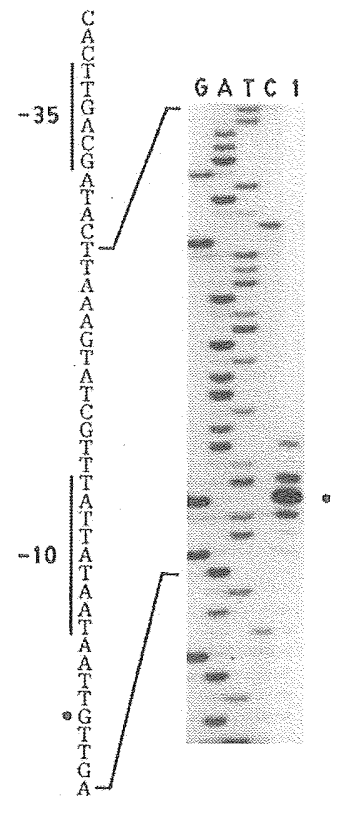

(B)

(a)

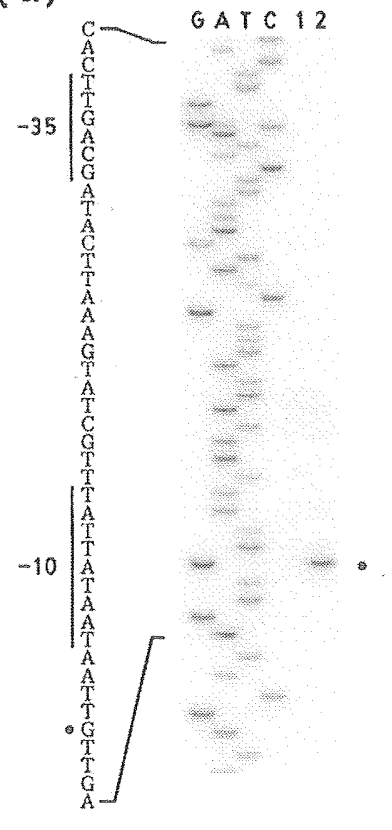

(b)

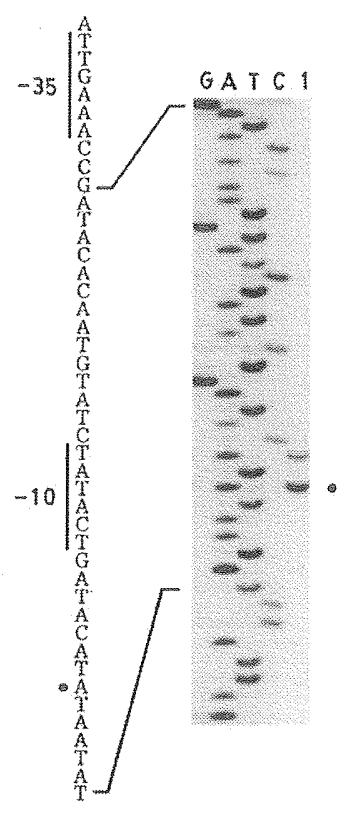

(b)

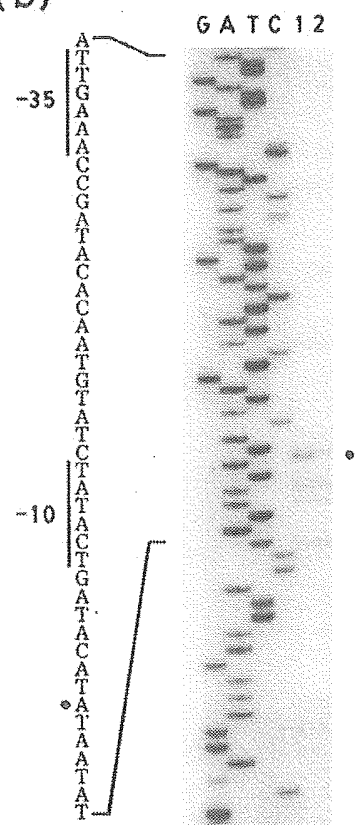

(c)

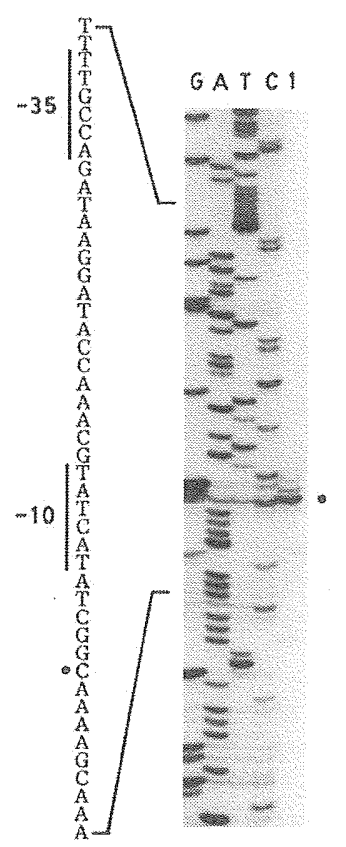

(c)

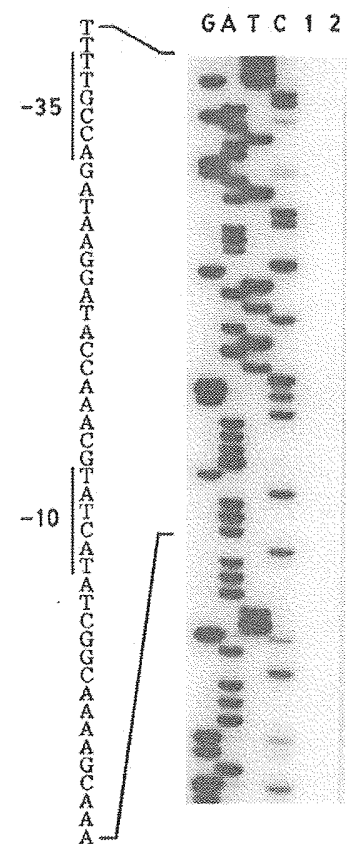


gested that cng can repress $p R$ as well as $p L$, although there remains a possibility that the 5 -end and the 5 -untranslated region of the pACYC184 cat gene may interfere with cat expression from the pKK232-8 derivatives.

\subsection{Overproduction and DNA-binding of Cng}

To determine whether cng actually directs synthesis of the protein Cng, a 267 bp region including cng was amplified by PCR using primers CNG I and II (Table 2), which carry additional $\mathrm{Ndel}$ and $\mathrm{BamHI}$ sites, respectively. The PCR fragment was introduced into $E$. coli vector pET-3c at the Ndel/BamHI sites, yielding $\mathrm{pE} 3 \mathrm{CNG} 1$. Primary structure of the cloned region was confirmed by DNA sequencing. E. coli BL21(DE3)plys $S$ carrying pE3CNG1 grew almost normally at $37^{\circ} \mathrm{C}$ in LB broth, whereas BL2l(DE3)/pE3CNG1 could not multiply (Cng might be toxic in $E$. coli).

After induction by IPTG $(1 \mathrm{mM})$ at $37^{\circ} \mathrm{C}$, total proteins were extracted from $E$. coli BL21(DE3)plys $S / \mathrm{pE} 3 \mathrm{CNG} 1$, and subjected to Tricine-SDS-PAGE (Section 2.2). pE3CNG1 directed steadily increasing synthesis of a protein (Fig. 3B); its apparent molecular mass of about $10.5 \mathrm{kDa}$ corresponds well with that of Cng (10.1 kDa) predicted from DNA sequence (Kodaira et al., 1997). This protein was not detected in BL21(DE3)plysS/pET-3c. N-Terminal amino acid sequence of the overproduced protein (Section 2.2) showed that the amino acid alignments, MKRERLIAE, completely coincided with that predicted from DNA sequence (Fig. 1B).

To clarify whether Cng is able to bind the GATACboxes specifically, gel-shift assays (Section 2.1) were performed. When cell-free extract of $E$. coli BL21(DE3)plysS/pE3CNG1 was added to a $300 \mathrm{bp}$ Asel/Rsal DNA fragment (Fig. 4A: lanes 2-4) or a 231 bp PCR-produced DNA fragment (Fig. 4A: lanes 5-6) containing five GATAC-boxes (2-6), mobility of these DNA fragments was lowered. In addition, the mobility of the $231 \mathrm{bp}$ fragment shifted along with increase in Cng content (Fig. 4B).

\subsection{Transcription initiation sites from $\mathrm{pR}, \mathrm{pL}$ and $\mathrm{pR} 49$}

The transcription start points from $p R, p L$ and $p R 49$ were determined by primer extension analysis in $E$. coli as well as $L$. plantarum. Fig. $5 \mathrm{~A}$ shows the results in $E$. coli. From $p R$ (Fig. 5Aa), four 5 '-ends of the transcripts were detected: the major start point was mapped at position $616(\mathrm{G})$, and the other three minors were at positions 615(T), 617(T) and 619(A). From $p L$ (Fig. 5Ab), two initiation sites were mapped: the major one at position $718(\mathrm{~A})$ and the minor at $716(\mathrm{~A})$. On the other hand, $p R 49$ (Fig. 5Ac) exhibited three start points: the major was at position $351(\mathrm{C})$, and the two minors were at $352(G)$ and $353(G)$.

As reported previously (Kodaira et al., 1997), øgle is a lysogenic phage of L. plantarum G1e, and is inducible with MMC or UV. Primer extension analyses were thus performed in the G1e cells. Without MMC treatment, one major transcript from $p L$ was detected, and no substantial signals from $p R$ or $p R 49$ were obtained (Fig. 5B). The start point from $p L$ was mapped at position $718(\mathrm{~A})$ (Fig. 5Bb: lane 1), corresponding with that (A) in $E$. coli (Fig. 5Ab). When the Gle cells were treated with $M M C$ for $2 \mathrm{~h}$, a unique transcript from $p R$ emerged, but no transcripts were detected from $p L$ or $p R 49$ (Fig. 5B). The start site from $p R$ was mapped at position $616(\mathrm{G})$ (Fig. 5Ba: lane 2), coincident with that (G) in E. coli (Fig. 5Aa).

\section{Discussion}

In the present study, the putative promoters $p R, p L$ and $p R 49$ of L. plantarum phage øgle were investigated. In the E. coli system: (i) the $\varnothing \mathrm{gle}$ sequences $p R, p L$ and $p R 49$ probably functioned as promoters, (ii) cng directed a protein Cng with an apparent molecular mass of $10.5 \mathrm{kDa}$ on a SDS gel, and (iii) Cng specifically bound to a DNA region containing the GATAC-boxes. In addition, primer extension analyses demonstrated that the two potential promoters $p R$ and $p L$ work well in $L$. plantarum as well as in $E$. coli, suggesting that they function for the lytic and lysogenic pathways, respectively. Although $p R 49$ indicated a promoter-like function in $E$. coli, it may not play an important role in $L$. plantarum. Thus, these results suggest that the $c n g-c p g$ region of $ø \mathrm{gle}$ is involved in lysis-lysogeny decision, and Cng (and Cpg) may act as a repressor, presumably on the GATAC-boxes.

A $15 \mathrm{bp}$ consensus of the GATAC-boxes, 5'GATAC(N) 5 GTATC-3', shows no resemblance to those of other predicted operators of the Lactococcus phages r1t (Nauta et al., 1996) and BK5-T (Boyce et al., 1995). In general arrangement, ogle boxes 1 and 7 somewhat resemble operators of coliphage 186 (Neufing et al., 1996), FR and FL, respectively; FR is located downstream of a repressor gene apl directing the lysis pathway, whereas FL is within another repressor gene cl directing the lysogenic pathway (Dodd and Egan, 1996). Additionally, $p L$ of $ø g 1 \mathrm{e}$ resembles promoters controlling lysogenic life-cycles of the coliphage 186 (Neufing et al., 1996) and Mu (van Ulsen et al., 1996), which are weaker than their promoters for the lytic cycle.

Preliminary experiments have shown that, like $\mathrm{cng}$, cpg directs a protein, whose apparent molecular mass on a SDS-gel is about $16.0 \mathrm{kDa}$, corresponding well with that $(15.1 \mathrm{kDa})$ estimated from DNA sequencing (unpublished data). As in coliphages such as lambda 
and 186, the øgle lysis-lysogeny switch might be under a complicated control. Further studies on structure, expression and function of the ogle regulatory region, $c n g-c p g$, are now in progress.

\section{Acknowledgement}

We thank Dr H. Kimoto (Fukui Medical School) for amino-acid sequencing, and Dr F.W. Studier (Brookhaven National Laboratory) for bacterial strains.

\section{References}

Albright, R.A., Mossing, M.C., Matthews, B.R., 1996. High-resolution structure of an engineered Cro monomer shows changes in conformation reactive to the native dimer. Biochemistry 35, 735-742.

Boyce, J.D., Davidson, B.E., Hillier, A.J., 1995. Sequence analysis of the Lactococcus lactis temperate bacteriophage BK5-T and demonstration that the phage DNA has cohesive ends. Appl. Environ. Microbiol. 61, 4089-4098.

Brosius, J., 1984. Plasmid vectors for the selection of promoters. Gene $27,151-160$

Campbell, A., 1994. Comparative molecular biology of lambdoid phages. Annu. Rev. Microbiol. 48, 193-222.

Chang, A.C.Y., Cohen, S.N., 1978. Construction and characterization of amplifiable multicopy DNA cloning vehicles derived from the P15A cryptic miniplasmid. J. Bacteriol. 134, 1141-1156.

Davidson, B.E., Powell, I.B., Hillier, A.J., 1990. Temperate bacteriophages and lysogeny in lactic acid bacteria. FEMS Microbiol. Rev. 87, 79-90.

Dodd, I.B., Egan, J.B., 1996. DNA binding by the coliphage 186 repressor protein Cl. J. Biol. Chem. 271, 11532-11540.

Harley, C.B., Reynolds, R.P., 1987. Analysis of E. coli promoter sequences. Nucleic Acids Res. 15, 2343-2361.

Kakikawa, M., Oki, M., Tadokoro, H., Nakamura, S., Taketo, A., Kodaira, K.-I., 1996. Cloning and nucleotide sequence of the major capsid proteins of Lactobacillus bacteriophage øgle. Gene 175, $157-165$.

Kakikawa, M., Oki, M., Watanabe, N., Yasukawa, H., Masamune, Y., Taketo, A., Kodaira, K.-I., 1997. Characterization of the genes encoding integrative and excisive functions of Lactobacillus phage øgle: cloning, sequence analysis, and expression in Escherichia coli. Gene 185, 119-125.

Kodaira, K.-I., Oki, M., Kakikawa, M., Watanabe, N., Hirakawa, M., Yamada, K., Taketo, A., 1997. Genome structure of the Lactobacillus temperate phage $ø \mathrm{gle}$ : the whole genome sequence and the putative promoter/repressor system. Gene 187, 45-53.

Nauta, A., van Sinderen, D., Karsens, H., Smit, E., Venema, G., Kok, J., 1996. Inducible gene expression mediated by a repressor-operator system isolated from Lactococcus lactis bacteriophage rlt. Mol. Microbiol. 19, 1331-1341.

Neufing, P.J., Shearwin, K.E., Camerotto, J., Egan, J.B., 1996. The CI protein of bacteriophage 186 establishes lysogeny by activating a promoter upstream of the lysogenic promoter. Mol. Microbiol. 21, 751-761.

Oki, M., Kakikawa, M., Yamada, K., Taketo, A., Kodaira, K.-I., 1996. Cloning, sequence analysis, and expression of the gene encoding lytic functions of bacteriophage ogle. Gene 176, 215-223.

Oki, M., Kakikawa, M., Nakamura, S., Yamamura, E.-T., Watanabe, K., Sasamoto, M., Taketo, A., Kodaira, K.-I., 1997. Functional and structural features of the holin HOL protein of the Lactobacillus plantarum phage ogle: analysis in Escherichia coli system. Gene $197,137-145$

Pabo, C.O., Sauer, R.T., 1984. Protein-DNA recognition. Annu. Rev. Biochem. 53, 293 321 .

Ploug, M., Jansen, A.L., Barkholt, V., Determination of amino acid compositions and $\mathrm{NH}_{2}$-terminal sequences of peptides electroblotted onto PVDF membranes from tricine-SDS-PAGE: application to peptide mapping of human complement component C3'. 1989. Anal. Biochem. 181, 33-39.

Sambrook, J., Fritsch, E.F., Maniatis, T., 1989. Molecular Cloning: A Laboratory Manual, 2nd ed. Cold Spring Harbor Laboratory Press, Cold Spring Harbor, NY.

Shaw, W.V., 1975. Chloramphenicol acetyl transferase from chloramphenicol-resistant bacteria. Methods Enzymol. 43, 737-755.

Studier, F.W., Rosenberg, A.H., Dunn, J.J., Dubendorff, J.W., 1990. Use of T7 RNA polymerase to direct expression of cloned genes. Methods Enzymol. 185, 6089.

van de Guchte, M., Daly, C., Fitzgerald, G.F., Arendt, E.K., 1994. Identification of the putative repressor-encoding gene cl of the temperate lactococcal bacteriophage Tuc2009. Gene 44, 93-95.

van UIsen, P., Hillebrand, M., Zulianello, L., van de Putte, P., Goosen, N., 1996. Integration host factor alleviates the H-NS-mediated repression of the early promoter of bacteriophage Mu. Mol. Microbiol. 21, 567-578.

Yasukawa, H., Kakikawa, M., Masamune, Y., Taketo, A., Kodaira, K.-I., 1997. Purification and DNA-binding properties pf the integrase Int encoded by Lactobacillus plantarum phage. Gene 204, 219-225. 
and 186 , the $ø$ gle lysis-lysogeny switch might be under a complicated control. Further studies on structure, expression and function of the øgle regulatory region, $c n g-c p g$, are now in progress.

\section{Acknowledgement}

We thank Dr H. Kimoto (Fukui Medical School) for amino-acid sequencing, and Dr F.W. Studier (Brookhaven National Laboratory) for bacterial strains.

\section{References}

Albright, R.A., Mossing, M.C., Matthews, B.R., 1996. High-resolution structure of an engineered Cro monomer shows changes in conformation reactive to the native dimer. Biochemistry $35,735-742$.

Boyce, J.D., Davidson, B.E., Hillier, A.J., 1995. Sequence analysis of the Lactococcus lactis temperate bacteriophage BK5-T and demonstration that the phage DNA has cohesive ends. Appl. Environ. Microbiol. 61, 4089-4098.

Brosius, J., 1984. Plasmid vectors for the selection of promoters. Gene $27,151-160$

Campbell, A., 1994. Comparative molecular biology of lambdoid phages. Annu. Rev. Microbiol. 48, 193-222.

Chang, A.C.Y., Cohen, S.N., 1978. Construction and characterization of amplifiable multicopy DNA cloning vehicles derived from the P15A cryptic miniplasmid. J. Bacteriol. 134, 1141-1156.

Davidson, B.E., Powell, I.B., Hillier, A.J., 1990. Temperate bacteriophages and lysogeny in lactic acid bacteria. FEMS Microbiol. Rev. 87, 79-90,

Dodd, I.B., Egan, J.B., 1996. DNA binding by the coliphage 186 repressor protein CI. J. Biol. Chem. 271, 11532-11540.

Harley, C.B., Reynolds, R.P., 1987. Analysis of E. coli promoter sequences. Nucleic Acids Res. 15, 2343-2361.

Kakikawa, M., Oki, M., Tadokoro, H., Nakamura, S., Taketo, A., Kodaira, K.-I., 1996. Cloning and nucleotide sequence of the major capsid proteins of Lactobacillus bacteriophage øgle. Gene 175, 157-165.

Kakikawa, M., Oki, M., Watanabe, N., Yasukawa, H., Masamune, Y., Taketo, A., Kodaira, K.-I., 1997. Characterization of the genes encoding integrative and excisive functions of Lactobacillus phage øgle: cloning, sequence analysis, and expression in Escherichia coli. Gene 185, 119-125

Kodaira, K.-I., Oki, M., Kakikawa, M., Watanabe, N., Hirakawa, M. Yamada, K., Taketo, A., 1997. Genome structure of the Lactobacillus temperate phage ogle: the whole genome sequence and the putative promoter/repressor system. Gene 187, 45-53.

Nauta, A., van Sinderen, D., Karsens, H., Smit, E., Venema, G., Kok, J., 1996. Inducible gene expression mediated by a repressor - operator system isolated from Lactococcus lactis bacteriophage rlt. Mol. Microbiol. 19, 1331-1341.

Neufing, P.J., Shearwin, K.E., Camerotto, J., Egan, J.B., 1996. The CII protein of bacteriophage 186 establishes lysogeny by activating a promoter upstream of the lysogenic promoter. Mol. Microbiol. $21,751-761$.

Oki, M., Kakikawa, M., Yamada, K., Taketo, A., Kodaira, K.-I., 1996. Cloning, sequence analysis, and expression of the gene encoding lytic functions of bacteriophage øgle. Gene 176, 215-223.

Oki, M., Kakikawa, M., Nakamura, S., Yamamura, E.-T., Watanabe, K., Sasamoto, M., Taketo, A., Kodaira, K.-I., 1997. Functional and structural features of the holin HOL protein of the Lactobacillus plantarum phage ogle: analysis in Escherichia coli system. Gene 197, 137-145.

Pabo, C.O., Sauer, R.T., 1984. Protein-DNA recognition. Annu. Rev. Biochem. 53, 293-321.

Ploug, M., Jansen, A.L., Barkholt, V., Determination of amino acid compositions and $\mathrm{NH}_{2}$-terminal sequences of peptides electroblotted onto PVDF membranes from tricine-SDS-PAGE: application to peptide mapping of human complement component C3'. 1989. Anal. Biochem. 181, 33-39.

Sambrook, J., Fritsch, E.F., Maniatis, T., 1989. Molecular Cloning: A Laboratory Manual, 2nd ed. Cold Spring Harbor Laboratory Press, Cold Spring Harbor, NY.

Shaw, W.V., 1975. Chloramphenicol acetyl transferase from chloramphenicol-resistant bacteria. Methods Enzymol. 43, 737-755.

Studier, F.W., Rosenberg, A.H., Dunn, J.J., Dubendorff, J.W., 1990. Use of T7 RNA polymerase to direct expression of cloned genes. Methods Enzymol. 185, 60 89.

van de Guchte, M., Daly, C., Fitzgerald, G.F., Arendt, E.K., 1994. Identification of the putative repressor-encoding gene cl of the temperate lactococcal bacteriophage Tuc2009. Gene 44, 93-95.

van Ulsen, P., Hillebrand, M., Zulianello, L., van de Putte, P., Goosen, N., 1996. Integration host factor alleviates the H-NS-mediated repression of the early promoter of bacteriophage $\mathrm{Mu}$. Mol. Microbiol. 21, 567-578.

Yasukawa, H., Kakikawa, M., Masamune, Y., Taketo, A., Kodaira, K.-I., 1997. Purification and DNA-binding properties pf the integrase Int encoded by Lactobacillus plantarum phage. Gene 204, 219-225. 